\title{
Influence of traffic flow structure and its characteristics on calculation of pavement design
}

\author{
N.G. Gorshkova \\ Department of Automobile and Railroads \\ Belgorod State Technological University named after V.G. \\ Shukhov \\ Belgorod, Russian Federation
}

\begin{abstract}
In recent years the cargo carriage volume has ramped up dramatically, the structure of the traffic flow has changed, the number of vehicles with a loading capacity over 7 tons has increased thus causing the increase in the actual axle load on road pavement. Modern regulations regarding the calculation of flexible pavement fall behind modern requirements to road pavement and a new structure of the traffic flow, which causes the need to improve the calculation of pavement design and to change the loading design values taking into account real operating conditions.
\end{abstract}

The paper provides the calculation results for two options of road pavement design: following the existing regulations and taking into account the reasonable proposed loading design values (based on different constructive schemes of vehicles, different axle load, and increased tire pressure).

Keywords—traffic flow, axle loads, loading design values, road pavement.

\section{INTRODUCTION}

The design of flexible road pavement implies the subgrade stress factor (stress in a pavement layers and an underlying subgrade under the influence of transport loading), calculated according to the elasticity theory thus bringing a multiply construction to a two-layer design model. The approximate solutions based on elementary design schemes and nomograms on their basis are thus used.

A flexible round wheel plate with $D$ diameter transferring the evenly distributed load of $p$ value was used as the design loading scheme. The values of a wheel design unit pressure on road pavement $\mathrm{p}$ and design diameter $\mathrm{D}$ are set taking into account the design parameters of types of vehicles. The heaviest vehicle, which accounts to over $10 \%$ in the total traffic flow, is taken as the vehicle design type [1].

For the last 17 years the traffic flow underwent considerable changes, which should be definitely taken into account:

- cargo carriage volume increased on average by $20 \%$ within the considered period (Fig. 1);

- $\quad$ structure of traffic flow changed (from 2000 to 2016 the number of vehicle with a loading capacity over $7 \mathrm{t}$ increased from 13 to $28 \%$, including vehicle with a loading capacity over $10 \mathrm{t}$ - to $24.5 \%$; and vehicle with a loading capacity over $20 \mathrm{t}-$ up to $8.5 \%$ ) (Fig. 2.) $[2]$.

\author{
A.S. Zhuravlev \\ A.S. Zhuravlev
Department of Automobile and Railroads
State Technological University named after V.G. \\ A.S. Zhuravlev
Department of Automobile and Railroads
Belgorod State Technological University named after V.G. \\ Shukhov \\ Belgorod, Russian Federation \\ zhuravlev_as@edu.bstu.ru
}

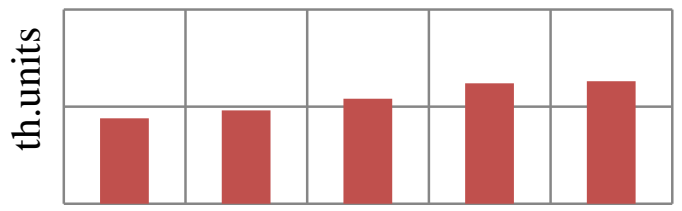

Fig.1. Change of the truck fleet structure

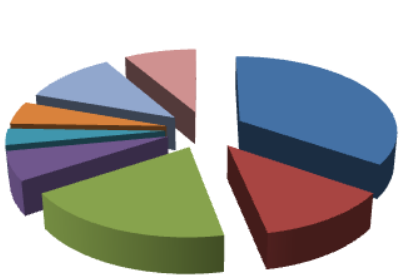

$$
\begin{aligned}
& \square \text { do } 1,5 t \\
& \text { over } 1,5 \text { to } 3 t \\
& \text { over } 3 t \text { to } 5 t \\
& \text { over } 5 t \text { to } 7 t \\
& \text { over } 7 \text { to } 10 t \\
& \text { over } 10 \text { to } 15 t \\
& \text { over } 15 \text { t to } 20 t \\
& \text { over } 20 t
\end{aligned}
$$

Fig.2. Truck fleet structure in 2016

The actual axle loads also increased. Motor carriers either overload their vehicles exceeding safe loading capacity, or use vehicles with a large number of axes to increase the payload and avoid surcharge axle loads. Different design regulations, standards and norms in road industry fall behind the development of automotive industry and numerous innovative technologies solving the main tasks of transport infrastructure development [3] thus leading to the reduction of the actual life cycle of road designs.

\section{METHODS AND MATERIALS}

At present, there is an urgent need to improve the pavement design method. It is obvious that the solution of this task requires a detailed study and analysis of dynamic influence of multi-axle vehicles since the stress-strain distribution of road pavements shows that multi-axle truck trains, which loads quite often exceed the standard, exert the main destructive impact on highways [4].

According to experts, the current design method of road pavement [1] is characterized by some problems that quite often lead to wrong design solutions.

The design load factor of a vehicle is determined as follows:

$$
S_{n \text { summary }}=\sum_{1}^{n} S_{n}
$$


where $n$ - number of axes of the given vehicle;

$S_{n}$ - coefficient of a rated dynamic load from a wheel of each vehicle axes against the design dynamic load determined as follows:

$$
S_{n}=\left(\frac{Q_{d n}}{Q_{d \text { calc }}}\right)^{P}
$$

where $Q_{d n}$ - rated dynamic wheel load on pavement:

$$
Q_{d n}=K_{d i n} \cdot Q_{n}
$$

where $K_{\text {din }}$ - impact factor set to 1.3 ;

$Q_{n}$ - rated static load on the given axis wheel;

$Q_{d \text { calc - design dynamic load on pavement: }}$

$$
Q_{\text {d calc }}=K_{\text {din }} \cdot Q_{\text {calc }}
$$

where $Q_{\text {calc }}$ - design load;

$P$ - for capital road pavement is set to 4.4 ; for intermediate -3.0 ; for transition -2.0 .

It is known that when defining the design value of the rated static load on a wheel there is a need to multiply the rated load specified in a technical certificate of a vehicle by $\mathrm{K}_{\mathrm{c}}$ ratio, which is calculated as follows:

$$
K_{\mathrm{c}}=a-b^{\sqrt{\mathrm{E}_{m}-c}}
$$

where $B_{m}$ - distance between outer axles (in meters);

$a, b, c$ - parameters defined depending on durability of road pavement and a number of axles.

\section{RESULTS.}

The Industry Road Code (ODM) 218.046 [1] indicates that the above calculation may be neglected and the $S_{n}$ may be set according to the table below:

TABLE I. DESIGN LOAD FACTOR

\begin{tabular}{|l|c|}
\hline \multicolumn{1}{|c|}{ Type of vehicle } & Design load factor \\
\hline Loading capacity from 1 to $2 \mathrm{t}$ & 0.005 \\
\hline Loading capacity from 2 to $5 \mathrm{t}$ & 0.2 \\
\hline Loading capacity from 5 to $8 \mathrm{t}$ & 0.7 \\
\hline Loading capacity over $8 \mathrm{t}$ & 1.25 \\
\hline Buses & 0.7 \\
\hline Tractor-trailer truck & 1.5 \\
\hline
\end{tabular}

The cumulative load factors specified in the regulations were calculated against traffic flow characteristics existing at the time of the document issue. It is also reasonable to mention the dynamic load factor according to ODM 218.11.001-2015 [5] since it is underestimated in certain cases [6]. Therefore there is a need to specify the cumulative load factors of vehicles against the design load based on characteristics of modern traffic flow.

Besides, Table 1 [1] is not complete since the classification of vehicles by loading capacity only without their design scheme does not reflect the real impact on road pavement. Thus, according to this table, KamAZ-43114 and MAZ-

\begin{tabular}{|c|c|c|c|c|c|}
\hline $\begin{array}{lll}\text { Parameter } & \text { Truck } \\
\end{array}$ & \multicolumn{2}{|c|}{ MAZ-533603-2121 } & \multicolumn{3}{|c|}{ KamAZ-43114 } \\
\hline Design concept & \multicolumn{2}{|c|}{ प्रों } & \multicolumn{3}{|c|}{ मुh } \\
\hline Weight, t. & \multicolumn{2}{|l|}{8,7} & \multicolumn{3}{|l|}{9,0} \\
\hline \multirow{2}{*}{ axle load, $t$} & 1axle & 2 axle & I axle & 2 axle & 3 axle \\
\hline & 4,85 & 3,85 & 4,5 & 2,27 & 2,27 \\
\hline Loading capacity, t & \multicolumn{2}{|l|}{7,8} & \multicolumn{3}{|l|}{6,4} \\
\hline Admissible weight, $t$ & \multicolumn{2}{|l|}{16.5} & \multicolumn{3}{|l|}{15,4} \\
\hline \multirow[b]{2}{*}{ axle load, $t$} & 1 & 2 & 1 & 2 & 3 \\
\hline & 6,5 axle & 10,0 axle & 5,4 axle & 5,0 axle & 5,0 axle \\
\hline
\end{tabular}
533603-2121 trucks refer to one type of vehicles (loading capacity from 5 to $8 \mathrm{t}$ ) but have different design schemes and axle loads (Fig. 3).

Fig. 3. Comparison of KamAZ-43114 and MAZ-533603-2121 specifications

The above vehicles have different effect on road design due to difference in design schemes and different axle load, therefore it is wrong to group them together with identical cumulative load factor [7].

The key load design factor used in the design of flexible road pavements is the axle or wheel load, the unit contact pressure and the diameter of a tread footprint. The contact pressure with vehicular deck $P_{a}$ is usually calculated through tire pressure taking into account the tire rate $P_{v}$. This was indicated in the Industry-Specific Construction Standards (VSN) 46-72 Guidelines on Flexible Pavement Design [8].

$$
P_{a}=P_{v} \cdot K_{g}, M P a
$$

where $K_{g}$ - tire rate.

The contact pressure is taken into account in its explicit form to calculate stress and deformation and in its hidden form influences the key design characteristic of wheel-pavement interaction - diameter of a wheel plate.

Alongside with other industrial standards, the calculations

\begin{tabular}{|c|c|c|c|}
\hline \multirow{2}{*}{$\begin{array}{l}\text { Design load } \\
\text { group }\end{array}$} & \multirow{2}{*}{$\begin{array}{c}\text { Rated static axle } \\
\text { load, } \mathrm{kN}\end{array}$} & \multicolumn{2}{|c|}{ Load design } \\
\hline & & $\mathrm{P}_{\mathrm{a}}, \mathrm{MPa}$ & $\mathrm{D}, \mathrm{cm}$ \\
\hline $\mathrm{A}_{1}$ & 100 & 0.60 & $37 / 33$ \\
\hline $\mathrm{A}_{2}$ & 110 & 0.60 & $39 / 34$ \\
\hline $\mathrm{A}_{3}$ & 130 & 0.60 & $42 / 37$ \\
\hline
\end{tabular}
according to current ODN 218-046 consider the unified pressure value $P_{a}=0.6 \mathrm{MPa}$ for axle loads up to $13 \mathrm{t}$ (Tab. 2).

TABLE II. DESIGN PARAMETERS FOR DIFFERENT LOAD GROUPS ACCORDING TO ODN 218.046 dynamic factor 1.3) and values for a static wheel in the nominator (static load).

Thus, the increase in contact pressure is neglected, while the growing load attack is considered through the design diameter of a wheel print $[1,9]$. Another industry document ODM 218.2.062 [10] recommends to accept $\mathrm{P}=0.8 \mathrm{MPa}$ for design pressure of capital road pavement and $\mathrm{P}=0.7 \mathrm{MPa}$ for transition pavement.

The work [11] refers to the analysis of load characteristics based on modern reference materials, which demonstrate considerable lag of road standards behind consumer properties of tires of modern cargo vehicles. Following the requirements of the motor vehicle industry, tires are designed with recommended internal tire pressure, which is higher than the 
design contact $0.6 \mathrm{MPa}(0.7 \mathrm{MPa}, 0.8 \mathrm{MPa})$ even under smaller axle loads.

The analysis was conducted for two different groups: separately for groups of single and coupled wheels (Fig. 4, 5).

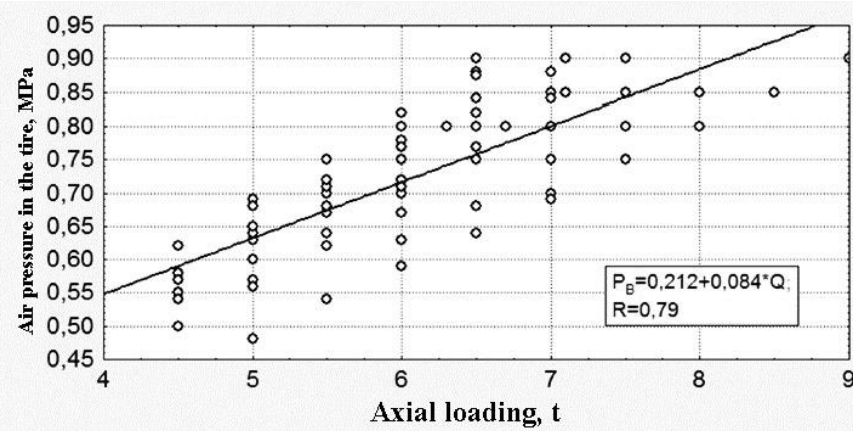

Fig. 4. Dependence of tire pressure of cargo vehicles with single wheels

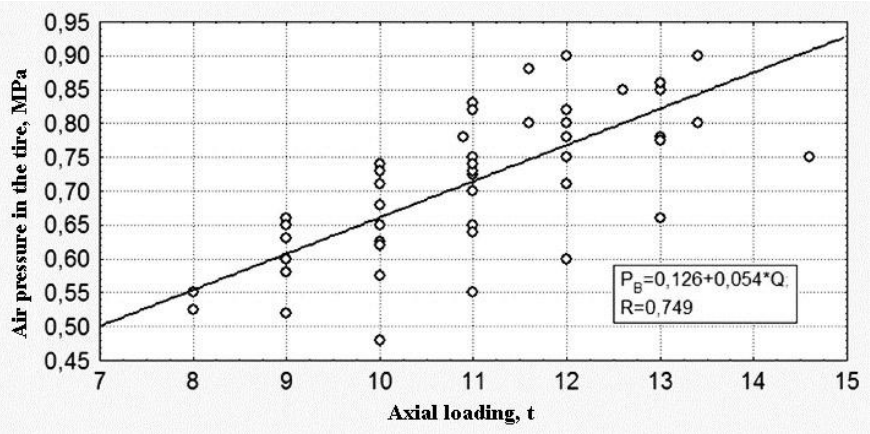

Fig. 5. Dependence of tire pressure of cargo vehicles with coupled wheels

The diagrams show that even without the rigidness of pressure and temperature, the unit pressure exceeds the standard design values and are close to the endurance strength of asphalt concrete under high summer temperatures, and in case of accumulated microdefects in asphalt concrete structure under relatively low positive temperatures. According to various estimates, during movement the tire warms up thus increasing the internal pressure to $20 \%$ of the initial one. During high temperature seasons, this is also fostered by thermal conditions of the environment. Thus, it is advisable to consider the transition from tire pressure to contact pressure in a more complex manner than it is currently accepted in road guidelines:

$$
P_{a}=P_{v} \cdot K_{g} \cdot\left(K_{g . r .}+\Delta_{t}\right) \cdot K_{N N}, M P a
$$

where $K_{g . r .}$ - pressure growth rate under movement (friction on coating, air internal friction);

$\Delta_{t}$ - environmental heat correction;

$K_{N N}$ - ratio considering the pressure difference between single and coupled wheels.

Assuming the fact that the average excess of contact pressure over internal tire pressure makes $20 \%$, considering that the difference in specific contact pressure of wheels with different design makes $10 \%$ and replacing the static load $\mathrm{A}_{2}$ from $110 \mathrm{kN}$ to $115 \mathrm{kN}$ [10], the following scale of load parameters was suggested (Tab. 3) [12].
TABLE III. LOAD DESIGN PARAMETERS FOR VARIOUS LOADING GROUPS

\begin{tabular}{|c|c|c|c|}
\hline Design & Rated static & \multicolumn{2}{|c|}{ Load design } \\
\cline { 3 - 4 } load group & axle load, $\mathrm{kN}$ & $\mathrm{P}_{\mathrm{a}}, \mathrm{MPa}$ & $\mathrm{D}, \mathrm{cm}$ \\
\hline $\mathrm{A}_{1}$ & 100 & 0.90 & $30 / 27$ \\
\hline $\mathrm{A}_{2}$ & 115 & 0.95 & $32 / 28$ \\
\hline $\mathrm{A}_{3}$ & 130 & 1.0 & $33 / 29$ \\
\hline
\end{tabular}

It should be noted that the road pavement design in compliance with the existing standards is only made for longitudinal areas (less than $30 \%$ ), which is not quite correct due to difference in the nature of vehicle impact on road pavement and its stress-strain distribution under slope. Moreover, the existing regulations on flexible pavement design do not consider the speed of trucks, i.e. the load time. In fact, when calculating the road pavement the load time is considered in values of dynamic modulus of elasticity and makes $0.1 s$, which does not correspond to the actual load time. This aspect was highlighted by Boguslavsky A.M., Radovsky B.S., Rudensky A.V., Smirnov A.V., Yakovlev Yu.M., etc. [13].

Two options of road pavement design meeting the necessary criteria were calculated using standard (Option 1) and proposed (Option 2) load design parameters. The calculations are made in Credo Radon for the most widespread type of pavement for public roads of the Belgorod Region:

- two-coarse pavement from stone mastic asphalt and dense coarse-grained asphalt concrete, Mark I, B type;

- base from porous coarse-grained asphalt concrete, Mark II and crushed-stone-sand mixture C-4;

- additional layer of the base from fine-grained sand with $5 \%$ silty-clayed fraction.

Option 1. Design region - central (Belgorod Region). Road category - II, two-lane road. Reliability factor -0.95 . Axle design weight $-115 \mathrm{kN}$. Required modulus of elasticity $-276 \mathrm{MPa}$. Tire pressure - 0.6 MPa. Tire plate diameter - 39 $\mathrm{cm}$.

TABLE IV. CHARACTERISTICS OF ROAD PAVEMENT

\begin{tabular}{|c|c|c|c|c|}
\hline No & Material & $\begin{array}{c}\text { Effective } \\
\text { thickness } \\
\text { of a layer, } \\
\mathrm{cm}\end{array}$ & $\begin{array}{l}\text { Total } \\
\text { modulus } \\
\text { of } \\
\text { elasticity, } \\
\mathrm{E}_{\text {общ, }} \mathrm{MPa}\end{array}$ & $\begin{array}{c}\text { Cost, } \\
\text { rub./sq.m. }\end{array}$ \\
\hline 1 & $\begin{array}{l}\text { Hot stone mastic } \\
\text { asphalt on } \\
\text { construction } \\
\text { bitumen } 60 / 90 \text {, } \\
\text { Mark I }\end{array}$ & 4 & 332 & 328,8 \\
\hline 2 & $\begin{array}{l}\text { Hot dense asphalt } \\
\text { on construction } \\
\text { bitumen } 60 / 90 \text {, } \\
\text { Type A, Mark I }\end{array}$ & 7 & 281 & 347,2 \\
\hline 3 & $\begin{array}{l}\text { Hot porous asphalt } \\
\text { on construction } \\
\text { bitumen } 60 / 90 \text {, } \\
\text { coarse-grained, } \\
\text { Mark II }\end{array}$ & 8 & 205 & 334,4 \\
\hline 4 & Slag macadam & 44 & 145 & 1038,4 \\
\hline
\end{tabular}




\begin{tabular}{|c|l|c|c|c|}
\hline & $\begin{array}{l}\text { sandy mixture for } \\
\text { active and mild } \\
\text { slag coatings C4 - } \\
40 \mathrm{~mm}\end{array}$ & 30 & 61 & 219 \\
\hline 5 & $\begin{array}{l}\text { Fine sand with 5\% } \\
\text { silty-clayed } \\
\text { fraction }\end{array}$ & - & 36 & - \\
\hline 6 & Light loam & 93 & Total cost & 2267,8 \\
\hline
\end{tabular}

Option 2. Design region - central (Belgorod Region). Road category - II, two-lane road. Reliability factor -0.95 . Axle design weight $-115 \mathrm{kN}$. Required modulus of elasticity - $347 \mathrm{MPa}$. Tire pressure - 0.95 MPa. Tire plate diameter - 32 $\mathrm{cm}$. When designing the road pavement based on ODN 218.046-01 the required modulus of elasticity under pressure other than 0.60 MPa (Option 2) was determined as follows:

$$
E_{f r}=\sqrt{\frac{P}{600}} \cdot 98,65(\log N-C)
$$

TABLE 5. Characteristics of road pavement

\begin{tabular}{|c|c|c|c|c|}
\hline No & Material & $\begin{array}{c}\text { Effecti } \\
\text { ve } \\
\text { thickne } \\
\text { ss of a } \\
\text { layer, } \\
\mathrm{cm}\end{array}$ & $\begin{array}{l}\text { Total } \\
\text { modulus of } \\
\text { elasticity, } \\
\mathrm{E}_{\text {общ, }}, \mathrm{MPa}\end{array}$ & $\begin{array}{c}\text { Cost, } \\
\text { rub./sq.m. }\end{array}$ \\
\hline 1 & $\begin{array}{l}\text { Hot stone mastic asphalt } \\
\text { on construction bitumen } \\
60 / 90 \text {, Mark I }\end{array}$ & 4 & 506 & 328,8 \\
\hline 2 & $\begin{array}{l}\text { Hot dense asphalt on } \\
\text { construction bitumen } \\
\text { 60/90, Type A, Mark I }\end{array}$ & 7 & 409 & 347,2 \\
\hline 3 & $\begin{array}{l}\text { Hot porous asphalt on } \\
\text { construction bitumen } \\
60 / 90 \text {, coarse-grained, } \\
\text { Mark II }\end{array}$ & 10 & 282 & 418 \\
\hline 4 & $\begin{array}{l}\text { Slag macadam sandy } \\
\text { mixture for active and } \\
\text { mild slag coatings } \mathrm{C} 4 \text { - } \\
40 \mathrm{~mm}\end{array}$ & 45 & 162 & 1062 \\
\hline 5 & $\begin{array}{l}\text { Fine sand with } 5 \% \text { silty- } \\
\text { clayed fraction }\end{array}$ & 30 & 66 & 219 \\
\hline 6 & Light loam & - & 36 & - \\
\hline & Total thickness: & & Total cost & 2375 \\
\hline
\end{tabular}

\section{CONCLUSION.}

The calculation results show that with the increase in tire pressure the wheel print diameter decreases alongside with the increase in the total design number of loads per pavement strip during the entire service life (approximately 5 times) and the increase in the required modulus of elasticity by $25 \%$. The following results were obtained based on design criteria:

- strength capacity in both options is almost identical;

- shear-resistance test in soil for the $2^{\text {nd }}$ option is at the limit;

- shear-resistance capacity in low-cohesive sandy layer in both options is quite big $(56 \%$ and $52 \%$ respectively);

- there is almost no extra capacity for the $2^{\text {nd }}$ option when calculating the shear-resistance of monolithic layers against bending-tensile test whereas for the $1^{\text {st }}$ option it makes $33 \%$.

Thus, the road pavement under increased tire pressure shall be quite thick. It turned out economically viable to increase the thickness of a low layer of porous asphalt concrete base by $2 \mathrm{~cm}$, which makes $25 \%$ of the thickness, for enhanced tire pressure rather than for accepted pressure of $0.60 \mathrm{MPa}$. It will lead to insignificant $(4.7 \%$ for the construction of road pavement) cost increase.

\section{References}

[1] ODN 218.046-01. Design of nonrigid road pavements; intr. 20.12.2001, M.: Management of innovations and technical standardization in road industry, 2001, pp. 107.

[2] Information and statistical bulletin Transport of Russia (JanuaryDecember, 2016), M: Ministry of Transport of the Russian Federation, 2017, pp. 72.

[3] Mechanistic-Empirical Design Guide (MEPDG): Interim Edition / AASHTO, Washington, 2008

[4] I.S. Titov, I.I. Batishchev "Cargo motor transport in Russia: state and perspectives," Transport of the Russian Federation, Vol. 5 (36), pp. 4448, 2012.

[5] ODM 218.11.001-2015, Methodical recommendations on accounting the increase in dynamic influence of loading under roughness and on defining the coefficient of dynamism depending on flatness indicator; intr. 04.12.2015, M.: Rosavtodor, 2015, pp. 81.

[6] Yu.A. Agafonov "Comments and suggestions," Road empire, Vol. 77, pp. 31, 2017.

[7] A.S. Konorev, Accounting of dynamic influence of multiaxis vehicles when calculating road designs: extended abstract of Cand. Tech. Sci. Dissertation: (05.23.11), Rostov-on-Don, 2012, pp. 24.

[8] Guidelines on flexible road design. BCH 46-72, M.: Transport, 1973, pp. 108

[9] MODN 2-2001, Design of flexible road pavements; intr. 15.12.2000, M.: Rosavtodor, 2000, pp. 76.

[10] ODM 218.2.062-2015, Recommendations on loading design parameter of modern vehicles: accepted and put into effect on the basis of the order of the Federal Road Transport Agency (Rosavtodor) No. 1736-r of 30.08.2016, M.: Federal Road Transport Agency (ROSAVTODOR), 2015, pp. 32.

[11] M.G. Goryachev, "Specification of design parameters of road loading," Science and technology in road industry, No. 3, pp. 14-15, 2013.

[12] M.G. Goryachev "Influence of actual loading parameters on calculation of durability of flexible pavements," Bulletin of BRR, Vol. 4, pp. 15-20, 2013.

[13] E.V. Kalenova, Improvement of calculation at flexible road design with asphalt pavements: extended abstract of Cand. Tech. Sci. Dissertation, Moscow Automobile and Road Construction State Technical University (MADI). Moscow. 2009, pp. 23 